\title{
Gliomas in Families
}

\author{
Y. Ikizler, D.J. van Meyel, D.A. Ramsay, G.L. Abdallah, R.M. Allaster, \\ D.R. Macdonald, W.K. Cavenee and J.G. Cairncross
}

\begin{abstract}
This is a descriptive study of 19 families with glial tumors. Twelve were identified prospectively from 178 consecutive, unrelated adults and children with newly diagnosed gliomas seen at a regional cancer center between 01 Jan 89 and 31 Mar $91(6.7 \%)$. There were 45 affected members (42 confirmed); 30 males, 15 females, ages 4 months-78 years (median, 44.5 years; mean, 38.9 years). Two families had four affected members, three families had three, and the others two. All confirmed tumors were supratentorial and all, save one, contained an astrocytic element. Three additional members of two families had other brain or neuroectodermal tumors. These families were not unusually cancer prone and did not appear to have neurofibromatosis, tuberous sclerosis, or colonic polyposis. There was no consistent pattern of inheritance.
\end{abstract}

RÉSUMÉ: Familles avec gliomes. Nous décrivons 19 familles avec tumeurs gliales. Douze de ces familles ont été identifiées de façon prospective à partir de 178 cas consécutifs, chez des adultes et des enfants non-apparentés, chez

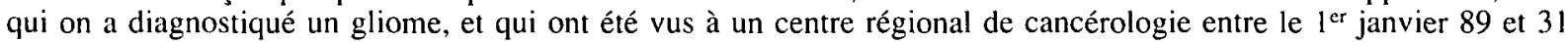
mars 91 (6.7\%). Parmi les 45 cas dans ces familles (42 diagnostics donfirmés), 30 étaient de sexe masculin et 15 de sexe féminin, entre 4 mois et 78 ans (âge médian 44.5 ans; âge moyen 38.9 ans). Deux familles avaient chacune 4 cas, 3 familles en avaient 3 et les autres 2. Toutes les tumeurs confirmées étaient sus-tentorielles et toutes sauf une avaienı un élément astrocytaire. Trois membres additionnels de 2 familles avaient d'autres tumeurs cérébrales ou neuro-ectodermiques. Ces familles n'étaient pas particulièrement sujettes au cancer et ne semblaient par atteintes de neurofibromatose, de sclérose tubéreuse ou de polypose colique. Il n'y avait pas de mode de transmission héréditaire particulier.

Can. J. Neurol. Sci. 1992; 19:492-497

Most gliomas occur sporadically with no known cause. There is circumstantial evidence that environmental insults, principally chemicals and radiation, predispose to glial tumors.' Severe head injury and longstanding seizure disorders may be additional risk factors. "Rare" families with glioma ${ }^{3-16}$ and the appearance of glial tumors in patients with neurofibromatosis, tuberous sclerosis, colonic polyposis, ${ }^{17.18}$ and the Li-Fraumeni syndrome, ${ }^{19-21}$ suggest that heritable genetic factors also play a role in glioma formation. Perhaps environmental factors trigger glial tumors in genetically predisposed persons, a speculation consistent with the current view that most adult cancers, including glioma, are the end result of a cascade of genetic abnormalities. ${ }^{22,23}$ We are studying hereditary influences and describe 19 families with glioma. These families have been ascertained by various means at a regional cancer center over three years. Not included in this report are eight additional families confirmed since preparing this manuscript and 12 in which gliomas have occurred in association with non-glial primary brain tumors (e.g., meningioma, medulloblastoma).

\section{METHODS}

Beginning 01 January 1989 all patients with newly diagnosed glial tumors referred to the London Regional Cancer Centre (LRCC) were questioned regarding a family history of brain tumor. Patients were interviewed on multiple occasions and, whenever possible, we questioned spouses, parents and other close relatives. Positive reports were pursued. Following accepted release of information procedures, we obtained pathology and autopsy reports on relatives suspected of having had a brain tumor and recorded the neuropathologic diagnosis. After confirming a positive family history of primary intracranial neoplasm, that is, two or more related individuals with pathologically documented tumors, we directed our attention to the families with glioma. Pedigrees were constructed and relationships between affected persons determined. Ethnic background and age at diagnosis were recorded, the latter was compared with tumor pathology within and between affected generations. The proband was re-examined, the affected relatives' records reviewed, and family members questioned for evidence of an

From the Departments of Oncology (Y.I., D.J.V.M., D.R.M., J.G.C.), Clinical Neurological Sciences (D.A.R., D.R.M., J.G.C.) and Pathology (D.A.R.), University of Western Ontario and London Regional Cancer Centre (G.L.A., R.M.A., D.R.M., J.G.C.), London; Ludwig Institute for Cancer Research (W.K.C.), San Diego Branch, San Diego

Received December 13, 1991. Accepted in final form May 14, 1992.

Reprint requests to: J. Gregory Cairncross, MD, London Regional Cancer Centre, 790 Commissioners Road, East, London, Ontario, Canada N6A 4L6 
hereditary neurocutaneous disorder, or colonic polyposis. Lastly, a detailed cancer history was obtained from each family. Other families were ascertained retrospectively by interviewing patients diagnosed and treated at this center prior to 1989 , and by reviewing our records. At least one affected member of each family, usually the proband, was a patient at the London Regional Cancer Centre. In each instance the patient was referred to the LRCC, the regional radiation facility, for neurooncologic assessment and treatment. Since we did not solicit familial cases, to our knowledge, referrals were not motivated by a family history of brain tumor, nor by our interest in "familial" cases.

\section{RESULTS}

We report 19 families with glial tumors. For brevity, the pedigrees presented in Figure 1 are restricted to patients, first degree relatives and "carriers". Twelve families were identified prospectively by interviewing 178 consecutive, unrelated adults and children with newly diagnosed gliomas seen at the LRCC between 01 Jan 89-31 Mar 91. During this interval 6.7\% of new patients had a blood relative with a glial tumor. Two families had four affected members, three families had three, and the others two. The relationship between the proband and other affected relatives was first degree in seven instances, second degree in eight, third degree in six, and distant in four. Except for families 1, 5, 8 and 9, the proband was a member of a recent generation, predeceased by his/her affected relative. Affected persons in families $2,7,10,12,17,18$ and 19 , at one point in time, occupied the same household. The illnesses overlapped temporally in families 5, 8, 9, 11 and 17. All families were Caucasian and of European descent. Perhaps of note, there were two Mennonite families (families 12, 16), two Dutch families (families 6,7), one Newfoundland family (family 5), one French Canadian family (family 18) and one Jewish family (family 19).

There were 45 affected persons, 30 males and 15 females. By reviewing surgical pathology and autopsy records we were able to confirm the diagnosis on 42 , all had supratentorial tumors (Table 1). There were 21 glioblastomas, 11 anaplastic astrocytomas, one anaplastic mixed glioma (oligoastrocytoma), six astrocytomas, one oligodendroglioma, and two mixed gliomas (oligoastrocytomas). Three unconfirmed cases are included in Figure 1. A female cousin of three affected brothers (family 7) had an "astrocytoma" according to her Dutch physician but we have not received a copy of the pathology report. Two distant relatives in families 3 and 6 are unsubstantiated but are included because in each family there were two other pathologically confirmed cases. Three additional members of families 3 and 6 had other brain or neuroectodermal tumors. The mother of the proband in family 3 had a meningioma. The paternal aunt of the proband in family 6 had neuroblastoma and his mother's identical twin sister had melanoma.

Age at diagnosis among confirmed cases ranged from four months to 78 years (median 44.5 years; mean 38.9 years). Seven patients, ages 16, 29, 36, 41, 56, 63 and 73 (four glioblastomas, two anaplastic astrocytomas, one astrocytoma), were diagnosed in the precomputed tomographic (CT) scan era. Figure 2 illustrates the distribution of low, intermediate and high grade gliomas (e.g., astrocytoma, anaplastic astrocytoma, glioblastoma) by age at diagnosis. Fifty percent of patients were diagnosed by age 45 , but more patients were diagnosed in the sixth decade of life, than any other. Patients with low grade and anaplastic gliomas were somewhat younger at diagnosis than those with glioblastoma. Table 2 demonstrates that patients from earlier generations were always older at diagnosis than those from recent ones (mean age 57.6 years vs 32.1 years) despite similar pathologies (i.e., malignancy stages). By way of contrast, Table 3 demonstrates that affected persons from the same generation tended to develop tumors at the same age despite a wider range of malignancy stages.

Twenty-eight affected individuals were examined by physicians or surgeons at this center (23 by DRM or JGC), none had the peripheral stigmata of tuberous sclerosis or neurofibromatosis type I. None of the patients or their relatives had acoustic neuromas or colonic polyposis and, apart from gliomas, were not unusually cancer prone. The other types of cancer that occurred in these families are listed in Table 4. There were two breast carcinomas, one osteosarcoma and one leukemia, but no soft tissue sarcomas or adrenal carcinomas. Only gastrointestinal malignancies occurred with any frequency. Interestingly, the proband in family 19, a 70-year-old man with a glioblastoma, had a small asymptomatic colon cancer at autopsy.

\section{Discussion}

The families described in this report do not appear to have neurofibromatosis type I, bilateral acoustic neurofibromatosis, tuberous sclerosis, or colonic polyposis, heritable disorders known to be associated with glioma. The possibility that these families have a "forme fruste" of the above, detectable at a molecular level, cannot be excluded. The frequency and distribution of other cancer types in these families effectively eliminates the Li-Fraumeni syndrome as an explanation for these "familial" cases but here again molecular analysis would be necessary to exclude the possibility of a variant disorder. Gliomas in families have suggested to some ${ }^{3-16}$ that heritable factors play a role in the genesis of glioma even in the absence of a predisposing hereditary syndrome. Perhaps the single most compelling report of this nature is one by Maroun et al. ${ }^{6}$ describing two interrelated Newfoundland families with ten affected persons in three generations. Recently, Lossignol et al. ${ }^{3}$ have observed that $9.4 \%(3 / 32)$ of patients with anaplastic astrocytomas enrolled in a treatment protocol at The Johns Hopkins Oncology Center had at least one first degree relative with an astrocytic tumor. They speculated that gliomas might occur in families more frequently than previously recognized. In our experience, over 27 months, $6.7 \%$ of newly diagnosed patients gave a positive and verifiable family history of glioma. The relationship between affected relatives was first degree in 3/12 families identified prospectively ( $7 / 19$ overall).

The appearance of gliomas in families is not necessarily evidence of inheritance. The methods we have used to ascertain and analyze these cases do not exclude the possibility that chance and environmental factors explain gliomas in families. Hochberg et al., ${ }^{24}$ in a case-control study of non-occupational risk factors for glioblastoma among 160 consecutive patients and 128 healthy controls, found that seven patients and 10 controls had a parent or sibling with a "brain tumor". These "positive" family histories were taken at face value and not verified pathologically, but nevertheless emphasize that gliomas are not rare illnesses and, by chance alone, could affect close relatives. 


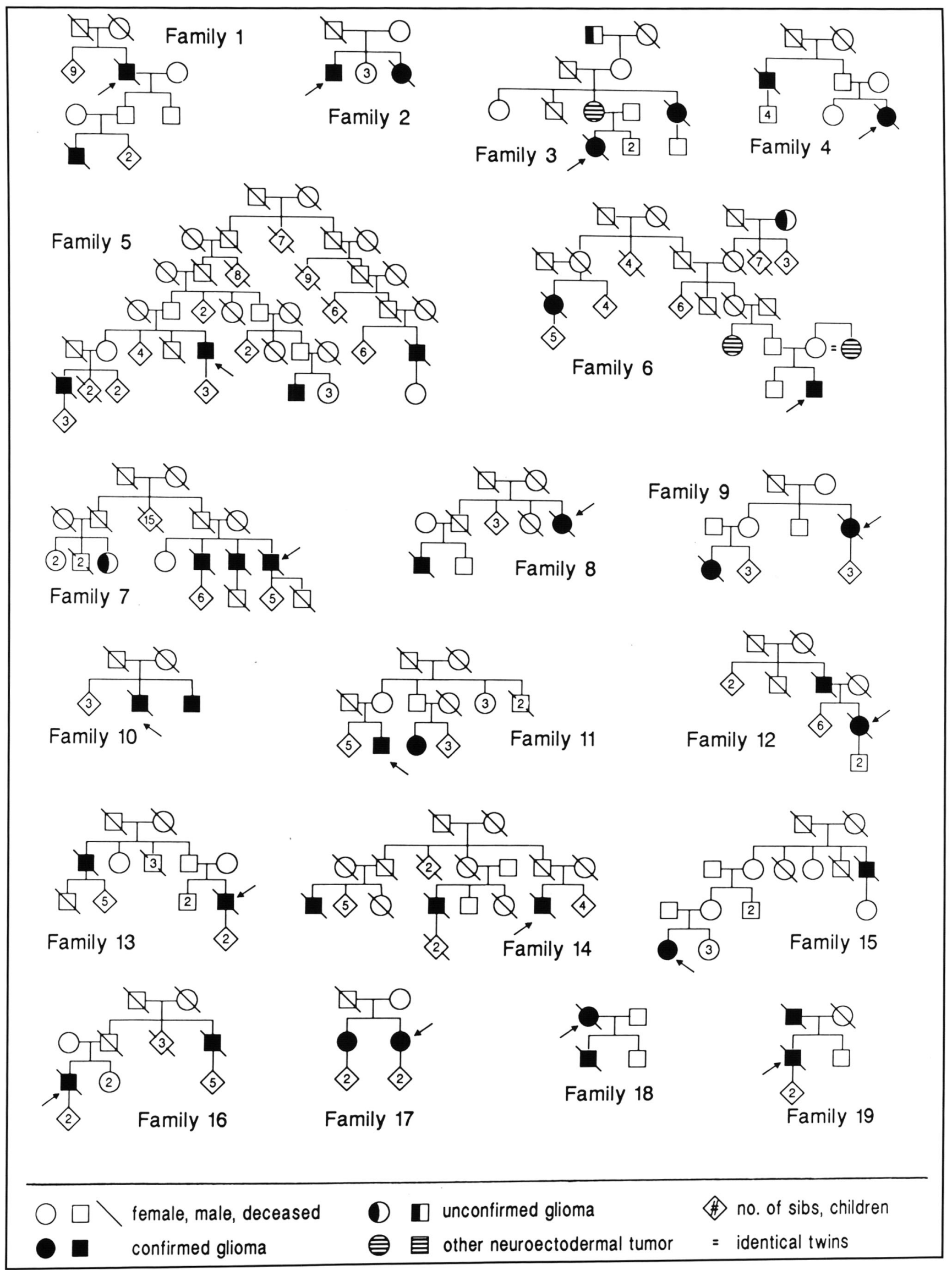

Figure I-Abbreviated pedigrees of 19 families with glioma (arrow indicates proband). 


\begin{tabular}{|c|c|c|c|}
\hline Family & Pathology & Family & Pathology \\
\hline 1 & $\begin{array}{l}\text { Glioblastoma (P) } \\
\text { Anaplastic Astrocytoma }\end{array}$ & 11 & $\begin{array}{l}\text { Mixed Glioma (P) } \\
\text { Astrocytoma }\end{array}$ \\
\hline 2 & $\begin{array}{l}\text { Anaplastic Astrocytoma (P) } \\
\text { Astrocytoma }\end{array}$ & 12 & $\begin{array}{l}\text { Glioblastoma }(P) \\
\text { Glioblastoma }\end{array}$ \\
\hline 3 & $\begin{array}{l}\text { Anaplastic Astrocytoma (P) } \\
\text { Glioblastoma }\end{array}$ & 13 & $\begin{array}{l}\text { Glioblastoma }(\mathrm{P}) \\
\text { Glioblastoma }\end{array}$ \\
\hline 4 & $\begin{array}{l}\text { Glioblastoma (P) } \\
\text { Anaplastic Astrocytoma }\end{array}$ & 14 & $\begin{array}{l}\text { Glioblastoma (P) } \\
\text { Glioblastoma (aunt's son) } \\
\text { Astrocytoma (uncle's son) }\end{array}$ \\
\hline 5 & $\begin{array}{l}\text { Astrocytoma (P) } \\
\text { Mixed Glioma (second cousin) } \\
\text { Anaplastic Astrocytoma (nephew } \\
\text { Glioblastoma (distant cousin) }\end{array}$ & 15 & $\begin{array}{l}\text { Anaplastic Astrocytoma (P) } \\
\text { Glioblastoma }\end{array}$ \\
\hline 6 & $\begin{array}{l}\text { Glioblastoma (P) } \\
\text { Glioblastoma }\end{array}$ & 16 & $\begin{array}{l}\text { Glioblastoma }(\mathrm{P}) \\
\text { Glioblastoma }\end{array}$ \\
\hline 7 & $\begin{array}{l}\text { Astrocytoma (P) } \\
\text { Glioblastoma } \\
\text { Anaplastic Astrocytoma }\end{array}$ & 17 & $\begin{array}{l}\text { Glioblastoma }(P) \\
\text { Oligodendroglioma }\end{array}$ \\
\hline 8 & $\begin{array}{l}\text { Anaplastic Astrocytoma (P) } \\
\text { Anaplastic Astrocytoma }\end{array}$ & 18 & $\begin{array}{l}\text { Glioblastoma (P) } \\
\text { Anaplastic Mixed Glioma }\end{array}$ \\
\hline 9 & $\begin{array}{l}\text { Glioblastoma (P) } \\
\text { Anaplastic Astrocytoma }\end{array}$ & 19 & $\begin{array}{l}\text { Glioblastoma }(\mathrm{P}) \\
\text { Glioblastoma }\end{array}$ \\
\hline 10 & $\begin{array}{l}\text { Astrocytoma (P) } \\
\text { Anaplastic Astrocytoma }\end{array}$ & & \\
\hline
\end{tabular}

$(\mathrm{P})=$ proband

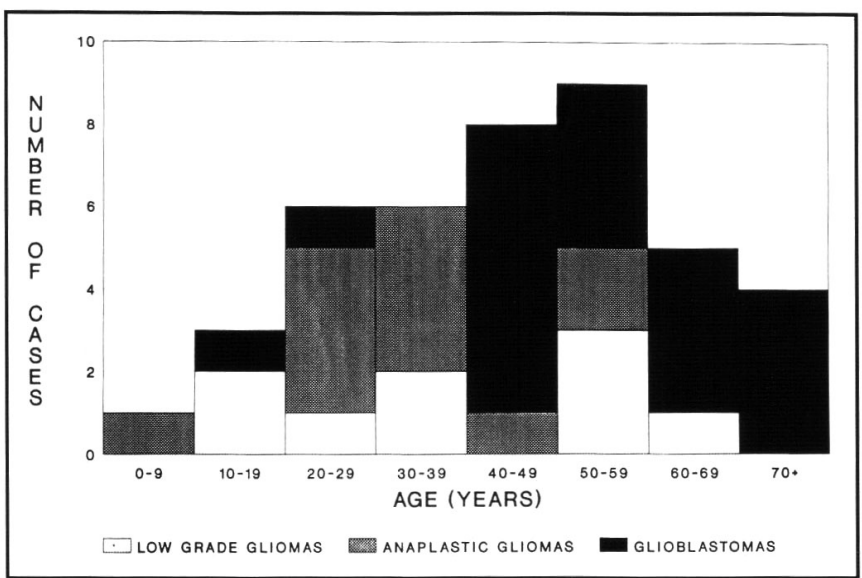

Figure $2-B a r$ graph demonstrating number of cases, age at diagnosis and pathology for 42 confirmed cases.

The probability of observing at least two affected persons in a family, given at least one affected person, can be estimated. For example, assuming an incidence for glioma of 4/100,000 population/year (i.e., the published age-adjusted incidence rate), 30 persons/family and 70 risk years/person, the probability of observing at least two glioma cases, given at least one, is $4 \%$. This generous estimate of chance occurrence in families is still smaller than the observed rate which may be as high as $6-9 \%$. We too think gliomas occur in families more frequently than predicted by chance, but are not certain. To clarify this issue we are now using spouses as case controls. Furthermore, family members often share a common environment and as such may share exposure to potential carcinogens. No environmental risk

Table 2. Comparison by Family of Age at Diagnosis and Pathology Among Affected Individuals From Different Generations

\begin{tabular}{|c|c|c|c|c|}
\hline \multirow{2}{*}{$\begin{array}{l}\text { Family } \\
\text { Number }\end{array}$} & \multicolumn{2}{|c|}{ Earlier Generation } & \multicolumn{2}{|c|}{ Later Generation } \\
\hline & Age & Pathology & Age & Pathology \\
\hline 1 & $57(\mathrm{P})$ & GBM & 4 months & $\mathrm{AA}$ \\
\hline 3 & 40 & GBM & $30(P)$ & AA \\
\hline 4 & 36 & $\mathrm{AA}$ & $24(P)$ & GBM \\
\hline \multirow[t]{2}{*}{5} & $60(P)$ & A & 29 & $\mathrm{AA}$ \\
\hline & 56 & GBM & 17 & MG \\
\hline 6 & 75 & GBM & $16(P)$ & GBM \\
\hline 8 & $59(\mathrm{P})$ & $\mathrm{AA}$ & 31 & $\mathrm{AA}$ \\
\hline 9 & $41(\mathrm{P})$ & GBM & 28 & $\mathrm{AA}$ \\
\hline 12 & 66 & GBM & $45(\mathrm{P})$ & GBM \\
\hline 13 & 78 & GBM & $44(P)$ & GBM \\
\hline 15 & 41 & GBM & $28(P)$ & $\mathrm{AA}$ \\
\hline 16 & 63 & GBM & $55(\mathrm{P})$ & GBM \\
\hline 18 & 62 & GBM & $32(P)$ & AMG \\
\hline 19 & 73 & GBM & $70(\mathrm{P})$ & GBM \\
\hline Average Age & 57.6 & & 32.1 & \\
\hline
\end{tabular}

$(\mathrm{P})=$ proband

$\mathrm{AA}=$ anaplastic astrocytoma

$\mathrm{MG}=$ mixed glioma

factors for glioma were identified in these families but our analysis was not exhaustive in this respect.

Gliomas, as they appeared in these families, were not remarkably different from "sporadic" cases in terms of male to female ratio, age at diagnosis, or distribution of tumor types. Of note, in families where affected persons were members of different generations, those from recent generations were invariably younger at diagnosis. Younger age at diagnosis in patients from 
Table 3. Comparison by Family of Age at Diagnosis and Pathology Among Affected Individuals From Identical Generations

\begin{tabular}{|c|c|c|c|c|c|c|}
\hline $\begin{array}{c}\text { Family } \\
\text { Number }\end{array}$ & Age & Pathology & Age & Pathology & Age & Pathology \\
\hline 2 & $40(P)$ & $\mathrm{AA}$ & 30 & A & - & - \\
\hline \multicolumn{7}{|c|}{5 (earlier generation) } \\
\hline & $60(P)$ & A & 56 & GBM & - & - \\
\hline \multicolumn{7}{|c|}{ (later generation) } \\
\hline & $29(\mathrm{P})$ & $\mathrm{AA}$ & 17 & MG & - & - \\
\hline 7 & $59(\mathrm{P})$ & A & 56 & GBM & 65 & $\mathrm{AA}$ \\
\hline 10 & $28(\mathrm{P})$ & A & 23 & $\mathrm{AA}$ & - & - \\
\hline 11 & $38(\mathrm{P})$ & MG & 16 & A & 一 & 一 \\
\hline 14 & $68(\mathrm{P})$ & GBM & 47 & GBM & 56 & A \\
\hline 17 & $47(P)$ & GBM & 50 & $\mathrm{O}$ & - & - \\
\hline
\end{tabular}

(P) $=$ proband

$A=$ astrocytoma

$\mathrm{AA}=$ anaplastic astrocytoma

$\mathrm{MG}=$ mixed glioma

$\mathrm{GBM}=$ glioblastoma

$\mathrm{O}=$ oligodendroglioma

Table 4. Cancers in the Families with Glioma

\begin{tabular}{lclc}
\hline \hline Cancer Type & $\begin{array}{c}\text { Number } \\
\text { of Cases }\end{array}$ & Cancer Type & $\begin{array}{c}\text { Number } \\
\text { of Cases }\end{array}$ \\
\hline Bladder & 1 & Osteosarcoma* & 1 \\
Breast* & 2 & Ovarian & 1 \\
Colorectal & 5 & Pancreas & 1 \\
Leukemia* & 1 & Prostate & 3 \\
Melanoma & 1 & "Stomach" & 5 \\
Myeloma & 1 & "Cancer" & 6 \\
Neuroblastoma & 1 & & \\
\hline
\end{tabular}

*Cancers associated with the Li-Fraumeni Syndrome.

recent generations is commonly observed in hereditary conditions and, in most instances, can be ascribed to earlier diagnosis or biased ascertainment of cases. Earlier diagnosis may result from anticipation by family members or their physicians, or improved diagnostic methods, or both. The cohort of family members at risk in a recent generation is younger-on-average than a similar cohort from an earlier generation; it follows that affected persons from a recent generation will also be youngeron-average. Presumably these factors explain the 25 -year age difference in this study, although it is conceivable that genetic mechanisms also contribute to younger age at diagnosis in affected persons from later generations.

If gliomas in these families are evidence of a heritable genetic abnormality causing brain tumors, what might it be? We can only speculate. Three important features of these families emerge from an analysis of Figure 1: first, males and females are affected; second, most family members are unaffected; third, there is no predictable pattern of inheritance. A dominant susceptibility gene of low penetrance ${ }^{25}$ might explain the patterns in families $1,3-6,8,9,11-16,18$ and 19 but the clustering of tumors in children of unaffected parents in families $2,7,10$ and 17 suggests a recessive gene. While it is conceivable that a heritable cancer might be transmitted between generations by a dominant mutation of variable penetrance, there is no convincing experimental evidence that this occurs in humans. On the other hand, there is considerable evidence that recessive mutations of growth suppressing genes lead to the heritable passage of cancer predisposition, as revealed by the retinoblastoma ( $R \mathrm{~b}$ ) paradigm. ${ }^{26}$ In this pediatric eye tumor for which both sporadic (unilateral) and familial (bilateral) cases exist, germ line heterozygosity for the mutant $\mathrm{Rb}$ allele is reduced to homozygosity by somatic mutation in the retina. Because somatic mutation occurs frequently in heterozygotes virtually all carriers develop retinoblastoma. The same appears to be true for the p53 gene and the Li-Fraumeni syndrome. ${ }^{20.21}$

Unlike retinoblastoma and the Li-Fraumeni syndrome, most individuals "at risk" in families with glioma remain unaffected. Any analogy between families with glioma and these inherited cancer syndromes must come to terms with this discrepancy. Recently, Sakai et al. ${ }^{27}$ have reported that naturally occurring point mutations in recognition sequences of the $\mathrm{Rb}$ gene promotor cause an hereditary low-penetrance retinoblastoma syndrome characterized by frequent asymptomatic or unilaterally affected carriers. Perhaps a similar mechanism involving another gene or multiple genes can be invoked to explain infrequent gliomas in families.

Searching for gliomas in families has taught us that a positive history is not always apparent initially, that a family member other than the patient is usually the best historian, and that most families are eager to cooperate. We continue to search for families with glioma, collecting blood and tumor wherever possible, believing that analysis of their DNA will one day facilitate the identification of genes important for glioma induction.

\section{ACKNOWLEDGEMENTS}

The authors thank the Victoria Hospital Research Development Fund, the Cancer Research Society Inc. and Dr. V. Bramwell for invaluable support, Dr. G. Ebers for advice and encouragement, C. Wong for statistical help, J. Berry and P. Payson for technical assistance and P. Gray for preparing the manuscript.

\section{REFERENCES}

1. Bakshi R, Ducatman AM, Hochberg FH. Glioblastomas in New England opthalmologists (letter). N Eng J Med 1991; 324: 14401441.

2. Hochberg F, Toniolo P, Cole P. Head trauma and seizures as risk factors of glioblastoma. Neurology 1984; 34: 1511-1514.

3. Lossignol D, Grossman SA, Sheidler VR, Griffin CA, Piantadosi S. Familial clustering of malignant astrocytomas. J Neuro-oncol 1990; 9: 139-145.

4. Duhaime AC, Bunin G, Sutton L, Rorke LB, Packer RJ. Simultaneous presentation of glioblastoma multiforme in siblings two and five years old: case report. Neurosurgery $1989 ; 24$ : 434-439.

5. Heuch I, Blom GP. Glioblastoma multiforme in three family members, including a case of true multicentricity. J Neurol 1986; 233: 142-144.

6. Maroun FB, Jacob JC, Heneghan WD, Managan MA, Russell NA, et al. Familial intracranial gliomas. Surg Neurol 1984; 22: 76-78.

7. Tijssen CC, Halrpin MR, Endtz LJ. Familial brain tumors. In: Martinus Nijhoff, ed. Developments in Oncology. Boston: 1982; 442-3.

8. Von Motz ID, Bots G, Endtz LJ. Astrocytoma in three sisters. Neurology 1977; 27: 1038-1041.

9. Isamat F, Miranda AM, Bartumeus F, Prat J. Genetic implications of familial brain tumors. J Neurosurg 1974; 41: 573-575.

10. Kaufman HH, Brisman R. Familial gliomas: report of four cases. J Neurosurg 1972; 37: 110-112.

11. Armstrong RM, Hanson CW. Familial gliomas. Neurology 1969; 19: $1061-1063$. 
12. Kjellin K, Muller R, Astrom KE. The occurrence of brain tumors in several members of a family. J Neuropathol Exp Neurol 1960; 19: 528-537.

13. Munslow RA, Hill AH. Multiple occurrences of gliomas in a family. J Neurosurg 1955; 12: 646-650.

14. Parkinson D, Hall CW. Oligodendrogliomas. Simultaneous appearance in frontal lobes of siblings. J Neurosurg 1962; 19:424-426.

15. Joughin JL. Coincident tumor of the brain in twins. Arch Neurol Psychiatr 1928; 19:948-950.

16. Fairburn B, Urich H. Malignant gliomas occurring in identical twins. J Neurol Neurosurg Psychiatry 1971; 34: 718-722.

17. Turcot J, Despres JP, St. Pierre F. Malignant tumors of the central nervous system associated with familial polyposis of the colon. Report of two cases. Dis Colon Rectum 1959; 2: 465-468.

18. Mastronardi L, Ferrante L, Lunardi P, et al. Association between neuroepithelial tumor and multiple intestinal polyposis (Turcot's syndrome): report of a case and critical analysis of the literature. Neurosurgery 1991; 28: 449-452.

19. Li FP, Fraumeni JF, Mulvihill JJ, Blattner WA, Dreyfus MG, et al. A cancer family syndrome in twenty-four kindreds. Cancer Res 1988; 48: 5358-5362.
20. Malkin D, Li FP, Strong LC, et al. Germ line p53 mutations in a familial syndrome of breast cancer, sarcomas and other neoplasms. Science 1990; 250: 1233-1238.

21. Srivastav S, Zou Z, Pirollo K, Blatıner W, Chang EH. Germ-line transmission of a mutated $p 53$ gene in a cancer-prone family with Li-Fraumeni syndrome. Nature $1990 ; 348: 747-749$.

22. Fearon ER, Vogelstein B. A genetic model for colorectal tumorigenesis. Cell 1990; 61: 757-767.

23. Mikkelson T, Cairncross JG, Cavenee WK. Genetics of the malignant progression of astrocytoma. J Cell Biochem 1991; 46: 3-8.

24. Hochberg F, Toniolo P, Cole P. Nonoccupational risk indicators of glioblastoma in adults. J Neuro-oncol 1990; 8: 55-60.

25. Martin GM, Schellenberg GD, Wijsman EM. Bird TD. Dominant susceptibility genes. Nature 1990; 347: 124.

26. Lee W-H, Bookstein R, Lee EY-HP. Studies on the human retinoblastoma susceptibility gene. J Cell Biol 1988; 212: 15-29.

27. Sakai T, Ohtani N, McGee TL, Robbins PD, Dryja TP. Oncogenic germ-line mutations in Spl and ATF sites in the human retinoblastoma gene. Nature 1991; 353: 83-86. 